\title{
AKTUELL KURSLITTERATUR FÖR HÖGSKOLAN

\author{
Från fabler till manga, Lärande genom skönlitteratur \\ och Skönlitteratur för barn och unga
}

\begin{abstract}
Ann Boglind och Anna Nordenstam. Från fabler till manga I:
Litteraturhistoriska och didaktiska perspektiv på barnlitteratur. Malmö: Gleerups, 2015. Skrifter utgivna av Svenska barnboksinstitutet, $\mathrm{nr}$ I3I (398 s.)
\end{abstract}

Ann Boglind och Anna Nordenstam. Från fabler till manga 2:

Litteraturhistoriska och didaktiska perspektiv på ungdomslitteratur. Malmö: Gleerups, 2016. Skrifter utgivna av Svenska barnboksinstitutet, $\mathrm{nr} 132$ (272 s.)

Mary Ingemansson. Lärande genom skönlitteratur: Djupläsning, förståelse, kunskap. Lund: Studentlitteratur, 2016 (200 s.)

Lena Kåreland. Skönlitteratur för barn och unga: Historik, genrer, termer, analyser. Lund: Studentlitteratur, 2015 (248 s.)

Att välja litteratur till kurser i barn- och ungdomslitteratur är en stor utmaning, speciellt när litteraturlistan till en kurs på lärarutbildningen ska färdigställas. I det följande granskas fyra nyutkomna titlar som alla ger ett bidrag till kurslitteraturutbudet på detta område. Först presenteras de fyra böckernas anspråk och styrkor. Därefter följer en diskussion kring anknytningen till tidigare forskning, referenshanteringen och de didaktiska anslagen.

I Ann Boglind och Anna Nordenstams Från fabler till manga 1. Litteraturhistoriska och didaktiska perspektiv på barnlitteratur (2015) och Från fabler till manga 2. Litteraturhistoriska och didaktiska perspektiv på ungdomslitteratur (2016) ges en bred överblick över barn- och ungdomslitteraturens historik, samtida tillstånd och genrer. Del 1 behandlar barnlitteratur och del 2 ungdomslitteratur. Båda böckerna inkluderar förslag till didaktiska upplägg som presenteras i slutet av flertalet kapitel samt ett avslutande didaktiskt kapitel. Commons Attribution-Noncommercial 3.0 Unported License (http://creativecommons.org/ licenses/by-nc/3.0/), permitting all non-commercial use, distribution, and reproduction in any medium, provided the original work is properly cited.

Citation: Barnboken - tidskrift för barnlitteraturforskning/Barnboken - Journal of Children's Literature Research, Vol. 40, 2017 http://dx.doi. org/10.14811/clr.v40i0.282 
Tillsammans ger böckerna en rik översikt över barn- och ungdomslitteraturens utveckling och nuvarande tillstånd. Att två delar har ersatt den första utgåvan av Från fabler till manga. Litteraturhistoriska och didaktiska perspektiv på barn- och ungdomslitteratur (2010) medför att lärarstudenter kan läsa den del som riktar sig mot den åldersgrupp som deras lärarutbildning inriktar sig mot. Den tydliga forskningsanknytningen, vilken syns i de frekventa referenserna till tidigare forskning, gör böckerna relevanta för både studenter och forskare i linje med beskrivningen av den tänkta målgruppen (Från fabler till manga 17; Från fabler till manga 215). Problematiseringen av begreppen barn- och ungdomslitteratur klargör på ett tydligt sätt att begreppens gränser är flytande.

Även Lena Kåreland har tagit sig an uppgiften att täcka in ett brett område i Skönlitteratur för barn och unga. Historik, genrer, termer, analyser (2015). Bokens målgrupp är i första hand studenter på lärarutbildningen och aktiva lärare (13). Till skillnad från Boglind och Nordenstam ger Kåreland inte några konkreta undervisningstips (7). Kapitlet "Barnbokens kontexter" utgör det starkaste, då det placerar in barnlitteraturen i förhållande till vuxenlitteraturen, det akademiska studiet av den samt olika sociala kontexter, såsom skolan. Avsnittet utgör en god introduktion till barnlitteraturens funktion i olika samhällssfärer. Att faktaböcker, en sorts litteratur som ofta hamnar i skymundan, får ett eget avsnitt är också en tillgång. Exempelanalyserna utifrån (barn)litterära teorier i kapitlet "Barnboken i teorin" som påminner om Paul Tenngarts upplägg i Litteraturteori (2008) bidrar till ett klargörande av hur olika teorier kan appliceras.

Mary Ingemanssons övergripande frågeställning i Lärande genom skönlitteratur. Djupläsning, förståelse, kunskap (2016) är hur lärare kan stötta sina elever till att bli "effektiva djupläsare" (13). Djupläsning utgör en översättning av det engelska begreppet "close reading" och avser för Ingemansson "den läsning som inbegriper omläsning och textsamtal" (25). Till skillnad från de övriga böckerna har Ingemanssons bok genomgående en didaktisk inriktning. Boken riktar sig enligt baksidestexten till lärarstudenter och aktiva lärare. Introduktionen av Judith A. Langers och Aidan Chambers teorier kring skönlitteratur och boksamtal, vilka tillämpas i egna empiriska klassrumsundersökningar, är föredömlig och ger inspiration till examensarbeten. Det finns inslag av konkreta handbokstips, såsom en lista med boksamtalsfrågor utifrån Langers teori (131). Kapitlet "Lärare lär om läsdidaktik" belyser fortbildning av lärare och klargör förtjänstfullt vikten av att förstärka kopplingen mellan didaktisk forskning och konkreta undervisningspraktiker. 
De fyra titlarna förhåller sig i hög grad till tidigare forskning, men de lyckas olika väl i sin strävan efter att ge en uppdaterad bild av forskningen. Boglind och Nordenstams böcker täcker in ett stort antal akademiska texter. I det didaktiska kapitlet i respektive bok inkluderas forskning som är inriktad mot den åldersgrupp av elever som respektive volym riktar sig mot. På några ställen saknas en mer utförlig behandling av facklitterära titlar, såsom Roberta Seelinger Trites inflytelserika Disturbing the Universe. Power and Repression in Adolescent Literature (2000). Trites huvudtes nämns kort (34), men studien hade kunnat bidra med en tydligare distinktion mellan barnoch ungdomslitteratur. Jerry Määttäs avhandling Raketsommar. Science fiction i Sverige 1950-1968 (2006) hade kunnat förtydliga distinktionen mellan science fiction och fantasy (jfr Från fabler till manga 1 203). Överlag fungerar böckerna dock väl även som forskningsöversikter. En diskussion om hur fördelningen av skönlitteratur på de olika volymerna har gått till hade dock bidragit till en större genomskinlighet kring de definitioner av barn- respektive ungdomslitteratur som författarna använder sig av.

Kåreland ämnar ge en kortfattad översikt över olika genrer, men den är i mitt tycke alltför skissartad. Exempelvis saknas central forskning om flick- och pojkboken som Marika Andraes Rött eller grönt? Flicka blir kvinna och pojke blir man i B. Wahlströms ungdomsböcker 1914-1944 (2001) och Birgitta Theanders Älskad och förnekad. Flickboken $i$ Sverige 1945-65 (2006). Kåreland framhåller att översikten inte ger anspråk på att vara heltäckande, utan ämnar "lyfta fram vissa typiska titlar" (64). Med nödvändighet måste många verk uteslutas, men frågan är vilken funktion det korta kapitlet kan fylla på en kurs i barnlitteratur om det inte inkluderar helt centrala titlar för genrer såsom fantasy där varken J. K. Rowlings eller J. R. R. Tolkiens verk nämns (78-80). Snarare är det den allmänna diskussionen om genrebegreppet och hur detta kan appliceras på barnlitteratur som tillför viktiga förtydliganden (53-62), medan Boglind och Nordenstams böcker tillfredsställer behovet av utförliga beskrivningar av genrer och historik.

Ingemanssons bok har en stark anknytning till forskning om läsutveckling $\mathrm{i}$ allmänhet, men speciellt genom vidareutvecklingen av Langers tankar och appliceringen av dessa i en svensk skolkontext. Däremot är kopplingen till den barnlitterära forskningen inte så utförlig, vilket syns tydligt i kapitel fyra som till skillnad från övriga kapitel är centrerat kring textanalys. En tydligare anknytning till barnlitterär terminologi och tidigare forskning hade förstärkt analysen. Förhållandet till den egenförfattade avhandlingen hade ock- 
så behövt förtydligas, exempelvis när Ingemansson konstaterar att "[f]orskning av Ingemansson (2010) ger trovärdighet åt" skildringen av historiska händelser (111). Den ospecifika hänvisningen till egen forskning gör det inte möjligt för läsaren att ta ställning till de forskningsresultat som hon baserar sin framställning på. I övrigt fungerar formalian dock väl.

Boglind och Nordenstams böcker inkluderar en ypperlig fotnotsapparat med sidhänvisningar. Referenshanteringen i Kårelands bok är däremot snårig. Det finns inget konsekvent system för när sidhänvisningar inkluderas respektive exkluderas. Ett större problem uppstår när placeringen av referenserna gör det oklart vad som är en redogörelse av tidigare forskning och vad som är författarens egna slutsatser, exempelvis när en referens till "(Steiner 2014, s. 75)" placeras i slutet av ett stycke men följs av ett flertal stycken med statistik som det inte uppges någon annan källa till (10-11).

De fyra böckerna inkluderar på olika sätt ett didaktiskt perspektiv. Boglind och Nordenstams didaktiska kapitel ger en lättillgänglig överblick över litteraturdidaktiska teorier. Dessa kapitel hade med fördel kunnat placeras tidigare i böckerna, så att teorin bakom lektionsuppläggen kommer före de konkreta förslagen. Som läsare av båda volymerna hade jag uppskattat om de didaktiska kapitlen hade varit mer olika. Till stor del innehåller de samma teorier och ofta också samma formuleringar (jfr Från fabler till manga 1 293; Från fabler till manga 2 200). Även Kåreland inkluderar ett kortare avslutande kapitel i vilket litteraturdidaktiska resonemang behandlas. Beklämmande nog relateras diskussionen till de numera ersatta kurserna Svenska A och B, trots att läroplanen för gymnasiet från 2011 precis har nämnts (198-199). Kapitlet om barnbokens kontexter ger dock som har framgått en god ingång till barnlitteratur i skolan. Ingemanssons bok är i sin helhet litteraturdidaktiskt inriktad, och den visar även upp resultat från egna empiriska undersökningar på ett lättillgängligt och praxisfokuserat sätt.

Sammantaget gör de fyra böckernas olika fokus att de kan komplettera varandra. Medan Boglind och Nordenstam ger en utförlig överblick över det barnlitterära fältet, dess genrer och dess historik bidrar Kåreland med en kortfattad introduktion till exempelvis barnlitteraturanalys. Ingemansson kompletterar med ett mer genomgående didaktiskt perspektiv och resultat från empiriska undersökningar som i samspel med de övriga böckerna kan skapa en brygga mellan barn- och ungdomslitteratur och litteraturdidaktik, vilket är centralt för blivande lärare som ska ta klivet från teori till praktik. Vid sammanställandet av en litteraturlista till en lärarutbildnings- 
kurs utgör Ingemanssons presentation av framförallt Langer och Chambers kombinerad med Boglind och Nordenstams historiska översikt, genrebeskrivningar samt didaktiska kapitel och handbokstips en god stomme. Kårelands exempelanalyser och inplacering av barnlitteraturen i olika sociala kontexter kan komplettera med en kortfattad introduktion till fenomenet barnlitteratur, men dess genrebeskrivningar och historik blir överflödig om Boglind och Nordenstams verk har inkluderats. De fyra böckerna kan således betraktas som ömsesidigt kompletterande i kurser på lärarutbildningen, men från Kårelands bok hade jag endast valt att inkludera ett fåtal, väl valda delar.

Malin Alkestrand

Lektor i litteraturvetenskap

Linnéuniversitetet 